\title{
The Value of Feedback in Primary Schools: Students' Perceptions of the Practice
}

\author{
Abatihun Alehegn Sewagegn \\ University of Johannesburg, South Africa \\ https://orcid.org/0000-0003-0147-5190 \\ Askalemariam Adamu Dessie \\ Debre Markos University, Ethiopia \\ https://orcid.org/0000-0001-8440-8879
}

\begin{abstract}
Feedback is a crucial aspect in assessment that enables students to learn from assessments received. The perception of the practice of feedback has an impact on the fruitfulness of the teachinglearning process. Hence, the main purpose of the study was to assess primary school students' perceptions of the practices of feedback. To attain this purpose, a descriptive survey design was used, and 474 students from two government and two private primary schools participated. Questionnaires and document reviews were used to collect data and analysed using quantitative and qualitative techniques. The results indicated that students favourably perceive the value and practice of feedback. Most of the students considered feedback as a provision of marks, grades, and correct answers. Yet, judgmental feedback using words such as "excellent", "very good" and "good" used in the students' exercise books have little value in showing learning gaps and as such, this type of feedback is not useful in improving students' learning. Therefore, for feedback to be useful, students should have a positive perception of feedback and take the feedback into account for future learning to enhance their knowledge and understanding.
\end{abstract}

Keywords: feedback; perception; practice; students; value

\section{Introduction}

Feedback refers to "commentary, verbal or written information that a student receives about their performance" (Marrs, 2016, p. 7). In the academic environment, feedback is an essential component and a vital strategy of the teaching-learning process (Ansari \& Usmani, 2018). If there is an assessment in the teaching-learning process, then there is feedback, and it is given in different forms to the students. Helping students to learn from their activities, mainly through encouraging dialogue, is a crucial aspect of feedback (Irons, 2008). 
Feedback is central to the development of effective educational practice (Sadler, 2010) and the students' perceptions of the practices of feedback have an impact on the fruitfulness of the teaching-learning process. The students' perceptions, understanding of the purpose, and beliefs about feedback are crucial determinants for achieving educational outcomes (Ansari \& Usmani, 2018). In the absence of meaningful feedback, good practices are not reinforced, poor performance is not corrected, and the path to improvement is not identified (Ansari \& Usmani, 2018).

According to Irons (2008) and Sadler (2010), the feedback given should be constructive to bring about improvement in students' learning. Constructive feedback helps learners to become more self-regulated, develop intrinsic motivation and positive self-esteem, identify and fill gaps in their current and future understanding, and encourages dialogue between teachers and students (Irons, 2008; Nicola \& Macfarlane-Dick, 2006). Therefore, a key aspect of effective feedback whether written or oral, is that the students need to learn what is required of them.

Effective feedback starts a thought process for students as it allows them to evaluate the quality of their work against that of their teacher or peers and empowers them to become self-regulated learners which effectively improves their learning abilities (Fautley \& Savage, 2008; Lee, 2006; Moss \& Brookhart, 2009; Sadler, 2010). According to Li and De Luca (2014), for feedback to be effective it should be timely and relate to the focus of the learning; it needs to acknowledge where the student has been successful and identify where and how improvement can take place. It also needs to be able to be clearly understood by the student, allowing them the time needed for improvement. According to Amua-Sekyi (2016), the feedback given becomes useful when it is provided quickly enough and acted upon to improve student's work and learning. The feedback should be of value to the student by 'closing the gap' on their understanding and providing an opportunity for dialogue to occur (Irons, 2008).

However, research evidences indicated as assessment results are not utilized effectively for the purpose of providing timely and constructive feedback rather used for grading purposes (Amua-Sekyi, 2016; Acar-Erdol \& Yildizli, 2018; Tan, Whipp, Gagné \& Quaquebeke, 2019). Therefore, this study assessed primary school students' perceptions of the practice of feedback. Unlike in other studies, in this research both quantitative and qualitative methods were used and students were the primary sources of the data. In other words, feedback should provide information about how the student did with regards to the desired aim or outcome and then further highlight how their performance could be improved (Tan, Whipp, Gagné \& Quaquebeke, 2019). Therefore, this study assessed primary school students' perceptions of the practice of feedback.

The topic of students' perceptions of the practice of feedback is an underresearched area, and there has been little empirical research published which focuses on students' perceptions of the practice of feedback at primary schools in 
the Ethiopian context. Moreover, to the knowledge of the researchers, in this study area and topic, no complete research has been done to assess students' perceptions of the practice of feedback to improve their learning at primary schools. Thus, based on these issues, the following research questions were raised.

- How do students perceive the value of feedback on their learning?

- How do students use feedback to improve their learning?

- To what extent do students' perceptions influence their use of feedback in their learning?

\section{Review of Literature}

\subsection{The link between assessment and feedback}

Assessment and feedback are the main components of the teaching-learning process, and there is a close link between the two. Hattie and Timperley (2007, p. 1) noted that "feedback is an essential component of assessment for learning", and when it is "used appropriately, can support students' learning and lead to substantial learning gains". Brookhart (2008) and Irons (2008) also stated that feedback is an essential component of the formative assessment process. Specifically, formative assessment and formative feedback are closely related (Irons, 2008). Irons (2008) also added that formative assessment and formative feedback are compelling and potentially constructive learning tools.

According to Oluwatayo, Irene and Appah (2014), feedback is the central function of formative assessment, and teachers' good feedback practices strengthen the students' capacity to self-regulate their performance. Feedback on assessments is an effective and efficient teaching and learning tool that is powerful in enhancing and strengthening students' learning (Sadler, 2010).

Quality feedback needs to be relevant to what is being assessed and to the learning process of the individual student. There are several ways of measuring the quality of feedback such as the timeline in which it is given (immediacy) and if it encourages students' learning and by how much (either too little or too much) (Irons, 2008). The most effective feedback is that which is given as close to the completion of the task as possible (Cowan, 2003 cited in Irons, 2008). As regular constructive feedback can have a positive impact on students' academic performance, not providing timely feedback will hamper their progress (Irons, 2008).

\subsection{Students' perceptions on the value of feedback}

Student's perceptions of feedback include what they believe the purpose of feedback is, how they feel about or value feedback that is given, and their interpretation of that feedback (Van Der Kleij \& Adie, 2020). Students might often find teachers' feedback confusing and very challenging to understand; often they might think they have understood the feedback when they have not, and even if they do manage to understand it, they may not know how to put it into practice (Sutton, Hornsey \& Douglas, 2011). 
Due to their perceptions and beliefs about feedback, students may not understand the importance of it and pay it little attention, focusing on getting good grades rather than on the comments received (Ansari \& Usmani, 2018; Carless, 2006). If the student does not know how to use the comments received to improve their work it undermines its effectiveness - this needs to be considered by teachers and schools when deciding on the format of their feedback practices (Bevan, Badge, Cann, Willmott, \& Scott, 2008 cited in Ansari \& Usmani, 2018).

As Irons (2008, p. 38) stated, "students can be demotivated as a result of feedback particularly when: they perceive the feedback to be unfair; feedback is unclear; they don't understand the feedback; the feedback doesn't seem to relate to the work they have done; they don't receive feedback in time; feedback is overly critical, and feedback is non-constructive". Spiller (2014) also noted that the following are the concerns of students regarding the feedback they are provided:

- Feedback comments are not understandable;

- Feedback does not point them in the right direction so that they can improve their work;

- The purpose of feedback is not clear to them;

- The relationship between the comments received and the grade given may create confusion;

- Feedback is either too much or too little;

- There are no opportunities to talk about the feedback;

- Feedback is not timely and therefore is not helpful;

- The reason why that specific feedback is given is unclear and

- Feedback comments can upset or embarrass a student.

\subsection{Value/use of feedback to improve students' learning}

Feedback can only be useful if students understand it and are willing and able to act on it (Price, Handley, Millar \& O'Donovan, 2010). As Marrs (2016) argues, it is most beneficial when students actively use the feedback they receive. Properly given feedback enhances the students' learning and has positive impacts on their performance. Irons (2008) listed the following positive benefits of feedback from the students' perspective:

- Feedback is used to learn;

- Feedback helps students to more fully understand their learning requirements and their subject understanding;

- Feedback can motivate students in their studies;

- Students are encouraged to try new ways of learning and

- Feedback can be used to reflect on learning practices and activities.

According to Di Costa (2010, p. 2), the characteristics of acceptable or good feedback practices are that they "clarify what good performance is; provide opportunities to close the gap; deliver high-quality information to students about their learning; facilitate the development of self-assessment (reflection) in learning; boost teacher and peer dialogue around learning; encourage positive 
motivational beliefs and self-esteem; and provide information to teachers that can be used to help shape teaching".

\section{Methods}

\subsection{Research Design}

The main purpose of the study was to assess students' perceptions of the practice of feedback to improve their learning in primary schools. To attain the purpose, a descriptive survey design was used. Both quantitative and qualitative methods were used in the study.

\subsection{Population, Participants and Sampling Techniques}

The study was carried out at Debre Markos primary schools. Government and private second cycle primary schools (grade 5 to 8 ) students were the population of the study. Biruhi Tesfa and Dibiza government primary schools and Lingerh and Selam Academy private primary schools were randomly selected. To determine the sample size, stratified random sampling was employed. In the strata, school and grade levels were considered. Finally, the sample sizes for each school were determined based on the sample size determination guidelines proposed by Cohen, Manion and Morrison (2018). Thus, the nearest sample numbers to the guideline were proposed for each school.

Table 1: Sample size from each primary school

\begin{tabular}{lccc}
\hline School name & Total No. students & \multicolumn{2}{c}{ Students } \\
\cline { 3 - 4 } & & $\mathrm{f}$ & $\%$ \\
\hline Biruhi Tesfa & 358 & 138 & 29.1 \\
Dibiza & 341 & 146 & 30.8 \\
Lingerh & 104 & 99 & 20.9 \\
Selam Academy & 89 & 89 & 18.8 \\
Total & $\mathbf{8 9 2}$ & $\mathbf{4 7 4}$ & $\mathbf{1 0 0 . 0}$ \\
\hline
\end{tabular}

Note: $\mathrm{f}=$ frequency; $\%$ = percentage

As indicated in Table 1, 138 (29.1\%) and 146 (30.8\%) students were selected from Biruhi Tesfa and Dibiza primary schools, respectively. Besides these, 99 (20.9\%) of the students were selected from Lingerh primary school, whereas $89(18.8 \%)$ of them were selected from Selam Academy. 474 students were selected in total from the four primary schools.

\subsection{Instruments}

To answer the research questions, data from questionnaires and document reviews were collected. A 5-point Likert scale questionnaire was used for the quantitative section of the study. The questionnaire (see Appendix 1) had three sub-scales (students' perceptions on the value of feedback which had 15 items, students' perceptions on the practice of feedback which had 14 items and feedback usage sub-scale which had 13 items). The questionnaire had 42 items, including the background information.

For the qualitative aspect, document review was used. The document review mainly focused on students' exercise books to assess the content and form of the teachers' feedback, whether it was judgmental or constructive. 


\subsection{Data Analysis}

To analyze the quantitative data, descriptive statistics (frequency, percentage, and mean) and inferential statistics (one sample t-test and multiple regression) value were employed. Moreover, correlation was computed to see the relationship between students' perceptions on the power of feedback and practice. To enhance clarity at the descriptive analysis level, specifically for percentage, it was decided to collapse the original 5-point Likert scale into three categories (Agree, Undecided, and Disagree) and (Often, Sometimes, and Rarely). According to Babbie (2010), collapsing Likert responses is acceptable when one wants to see a clearer pattern in the findings. The document review was analyzed qualitatively using words to triangulate the quantitative data.

\subsection{Reliability and Validity}

Reliability refers to the dependability, stability, and predictability of responses (Creswell, 2007; De Vos, Strydom, Fouche, \& Delport, 2011). To test the reliability of items in the questionnaire, a pilot study was conducted using 20 students, and Cronbach Alpha was used to analyze the reliability and the results for the three sub-scales were $0.594,0.588$ and 0.706 for students' perceptions on the power of feedback, students' perceptions of feedback practice, and its usage, respectively. After revision, the reliabilities of the students' questionnaire for the main study were $0.73,0.71$ and 0.756 for the above three sub-scales respectively, which is acceptable based on George and Mallery's (2003) standard.

To increase the validity of the questionnaire, three selected experts in education and psychology helped in reviewing the questions. De Vos et al. (2011) established that content validity and face validity of the instrument can be established on the basis of researchers' and other experts' judgments.

\section{Findings}

The findings were organized based on the research questions. In this section, students' perceptions on the value of feedback, perceptions on the practice of feedback and their use of feedback are presented.

\subsection{Students' perceptions on the value of feedback}

To determine the students' perceptions on the value of feedback on students' learning, 15 items were used, and the analysis was done using frequency, percentage, and mean as indicated in Table 2.

Table 2: Students' perceptions on the value of feedback

\begin{tabular}{|c|c|c|c|c|c|c|c|c|}
\hline \multirow{3}{*}{\multicolumn{2}{|c|}{ No. Items }} & \multicolumn{7}{|c|}{ Responses } \\
\hline & & \multicolumn{2}{|c|}{ Agree } & \multicolumn{2}{|c|}{ Neutral } & \multicolumn{3}{|c|}{ Disagree } \\
\hline & & $\mathrm{f}$ & $\%$ & $\mathrm{f}$ & $\%$ & $\mathrm{f}$ & $\%$ & Mean \\
\hline 1 & $\begin{array}{l}\text { Feedback is helpful to show gaps in } \\
\text { knowledge and understanding. }\end{array}$ & 425 & 89.3 & 16 & 3.4 & 32 & 6.8 & 4.32 \\
\hline 2 & $\begin{array}{l}\text { Feedback rarely provides me with } \\
\text { useful suggestions for improvement. }\end{array}$ & 42 & 8.9 & 48 & 10 & 378 & 79.8 & 2.01 \\
\hline 3 & $\begin{array}{l}\text { I consider that peer feedback is } \\
\text { essential for learning. }\end{array}$ & 303 & 63.9 & 94 & 19.8 & 73 & 15.4 & 3.66 \\
\hline 4 & Teacher feedback is effective in & 422 & 89 & 17 & 3.6 & 31 & 6.5 & 4.37 \\
\hline
\end{tabular}




\begin{tabular}{|c|c|c|c|c|c|c|c|c|}
\hline & promoting students' learning. & & & & & & & \\
\hline 5 & $\begin{array}{l}\text { Constructive criticism is needed to } \\
\text { know how to improve my work. }\end{array}$ & 299 & 63.1 & 56 & 11.8 & 114 & 24 & 3.58 \\
\hline 6 & $\begin{array}{l}\text { Feedback given at the end of the } \\
\text { subject is not useful. }\end{array}$ & 106 & 22.4 & 48 & 10.1 & 319 & 67.3 & 2.32 \\
\hline 7 & $\begin{array}{l}\text { The feedback which is given should } \\
\text { be clear to be helpful. }\end{array}$ & 442 & 93.2 & 15 & 3.2 & 17 & 3.6 & 4.49 \\
\hline 8 & $\begin{array}{l}\text { Feedback encouraged me to improve } \\
\text { my work. }\end{array}$ & 369 & 77.8 & 61 & 12.9 & 39 & 8.2 & 3.99 \\
\hline 9 & $\begin{array}{l}\text { Positive comments increase my } \\
\text { confidence. }\end{array}$ & 381 & 80.4 & 39 & 8.2 & 46 & 9.7 & 4.15 \\
\hline 10 & $\begin{array}{l}\text { I thought about giving up when I got } \\
\text { negative feedback. }\end{array}$ & 52 & 11 & 74 & 15.6 & 340 & 71.8 & 1.93 \\
\hline 11 & $\begin{array}{l}\text { I felt demoralized or angry after } \\
\text { reading negative feedback. }\end{array}$ & 134 & 28.3 & 85 & 17.9 & 248 & 52.4 & 2.58 \\
\hline 12 & $\begin{array}{l}\text { Feedback has helped me to reflect on } \\
\text { what I have learned. }\end{array}$ & 363 & 76.6 & 60 & 12.7 & 36 & 7.6 & 4.02 \\
\hline 13 & $\begin{array}{l}\text { I need to receive positive feedback to } \\
\text { progress. }\end{array}$ & 366 & 77.3 & 35 & 7.4 & 68 & 14.3 & 3.97 \\
\hline 14 & $\begin{array}{l}\text { I need to receive negative feedback to } \\
\text { progress. }\end{array}$ & 207 & 43.7 & 62 & 13.1 & 200 & 42.2 & 2.99 \\
\hline 15 & $\begin{array}{l}\text { Teachers' comments are vital in my } \\
\text { learning. }\end{array}$ & 448 & 94.5 & 10 & 2.1 & 15 & 3.2 & 4.66 \\
\hline
\end{tabular}

As indicated in Table 2, most students perceived that teachers' feedback is useful to promote their learning, to reflect on what they have learned, and to identify the learning gaps. Besides this, according to the perception of students, feedback should be clear, positive, and constructive to improve their learning and confidence.

$80.4 \%$ and $77.3 \%$ of students agreed on the value of positive feedback to increase their confidence and showed their interest in receiving such feedback to improve their learning, respectively. Even if $28.3 \%$ of the students agreed that negative feedback demoralizes them and affects their future learning, $43.7 \%$ of them perceived that the negative feedback given has the power to help them perform better in their future learning.

\subsection{Students' perceptions on the practice of feedback}

In Table 3, 14 items were included to assess students' perceptions on the practice of feedback by their teachers, and the analysis was done using frequency, percentage, and mean.

Table 3: Students' perceptions of the practice of feedback

\begin{tabular}{|c|c|c|c|c|c|c|c|c|}
\hline \multirow{3}{*}{ No } & \multirow{3}{*}{ Items } & \multicolumn{7}{|c|}{ Responses } \\
\hline & & \multicolumn{2}{|c|}{ Agree } & \multicolumn{2}{|c|}{ Neutral } & \multicolumn{3}{|c|}{ Disagree } \\
\hline & & $\bar{f}$ & $\%$ & $\mathrm{f}$ & $\%$ & $f$ & $\%$ & Mean \\
\hline 1 & $\begin{array}{l}\text { On the subject that I am learning, I } \\
\text { get plenty of feedback on how I am } \\
\text { doing. }\end{array}$ & 251 & 52.9 & 103 & 21.7 & 114 & 24 & 3.40 \\
\hline 2 & $\begin{array}{l}\text { Teachers give me immediate } \\
\text { feedback for each assessment. }\end{array}$ & 227 & 47.9 & 81 & 17.1 & 163 & 34.4 & 3.20 \\
\hline
\end{tabular}




\begin{tabular}{|c|c|c|c|c|c|c|c|c|}
\hline 3 & $\begin{array}{l}\text { There is hardly any feedback on my } \\
\text { assignments when I get them back. }\end{array}$ & & 19.6 & 67 & 14.1 & 311 & 65.6 & 3.56 \\
\hline 4 & $\begin{array}{l}\text { When I get things wrong, I don't } \\
\text { receive much guidance in what to } \\
\text { do about it. }\end{array}$ & 98 & 20.7 & 51 & 10.8 & 318 & 67.1 & 3.63 \\
\hline 5 & $\begin{array}{l}\text { I would learn more if I received } \\
\text { more feedback. }\end{array}$ & 372 & 78.4 & 49 & 10.3 & 47 & 9.9 & 4.10 \\
\hline 6 & $\begin{array}{l}\text { Teachers' feedback that comes too } \\
\text { late is not useful for learning. }\end{array}$ & 186 & 39.3 & 98 & 20.7 & 185 & 39 & 3.00 \\
\hline 7 & $\begin{array}{l}\text { Teachers provide enough feedback } \\
\text { on my work. }\end{array}$ & 307 & 64.7 & 62 & 13.1 & 93 & 19.5 & 3.60 \\
\hline 8 & $\begin{array}{l}\text { The feedback mainly tells me how } \\
\text { well I am doing in relation to } \\
\text { others. }\end{array}$ & 336 & 70.9 & 61 & 12.9 & 69 & 14.6 & 3.80 \\
\hline 9 & $\begin{array}{l}\text { Teachers' feedback is rarely written } \\
\text { with reference to the assessment } \\
\text { criteria. }\end{array}$ & 289 & 60.9 & 102 & 21.5 & 72 & 15.2 & 3.50 \\
\hline 10 & $\begin{array}{l}\text { The feedback given helps me to } \\
\text { understand things better. }\end{array}$ & 392 & 82.7 & 35 & 7.4 & 40 & 8.5 & 4.20 \\
\hline 11 & $\begin{array}{l}\text { The feedback given shows me how } \\
\text { to do better next time. }\end{array}$ & 408 & 86.1 & 25 & 5.3 & 37 & 7.8 & 4.20 \\
\hline 12 & $\begin{array}{l}\text { Once I have read the feedback, I } \\
\text { understand why I got the mark I } \\
\text { did. }\end{array}$ & 326 & 68.8 & 72 & 15.2 & 67 & 14.2 & 3.80 \\
\hline 13 & $\begin{array}{l}\text { I don't understand some of the } \\
\text { feedback given. }\end{array}$ & 198 & 41.8 & 97 & 20.5 & 172 & 36.3 & 3.10 \\
\hline 14 & $\begin{array}{l}\text { I can seldom see from the feedback } \\
\text { given what I need to do to improve. }\end{array}$ & 409 & 86.3 & 18 & 3.8 & 44 & 9.3 & 4.20 \\
\hline
\end{tabular}

As indicated in Table 3 above, most of the students perceived that the more feedback they receive from their teachers, the better they learn. The feedback given to the students helps them to understand things better $(82.7 \%)$ and shows how to do tasks better the next time $(86.1 \%)$. Even if $41.8 \%$ of the students sometimes do not understand some of the feedback given to them from their teachers, $86.3 \%$ of them perceived that they sometimes do understand the feedback given and what they need to do to improve their learning.

As shown in Table 3, $68.8 \%$ and $70.9 \%$ of the students agreed that the feedback given to them indicates why they got the mark they did and how well they are doing when compared to other students, respectively. Most students agreed that their teachers provide enough and timely feedback for different assessment tasks and provide guidance/support on how to do better the next time. However, $34.4 \%$ of the students agreed that their teachers do not provide immediate feedback to them.

Results from document review (students' exercise books) showed that the feedback which is given is general and judgmental such as excellent, very good, good, etc. In addition, teachers provide feedback in the form of marks or numbers. However, such types of feedback are less powerful in improving students' learning and do not clearly show what students did and did not do or highlight the learning gaps. 


\subsection{Students use of feedback to improve their learning}

Feedback was useful when we used the comments to identify learning gaps and to propose strategies for future learning. Here, 13 items were used to examine whether students were using the feedback given to improve their learning or not. The analyses were made using frequency, percentage, and mean. The results are indicated in Table 4 and 5 below.

Table 4: Students' use of feedback to improve their learning

\begin{tabular}{|c|c|c|c|c|c|c|c|c|}
\hline \multirow[t]{3}{*}{ No. } & \multirow[t]{3}{*}{ Items } & \multicolumn{7}{|c|}{ Responses } \\
\hline & & \multicolumn{2}{|c|}{ Rarely } & \multicolumn{2}{|c|}{ sometimes } & \multicolumn{3}{|c|}{ Often } \\
\hline & & $\mathrm{f}$ & $\%$ & $\mathrm{f}$ & $\%$ & $\mathrm{f}$ & $\%$ & Mean \\
\hline 1 & $\begin{array}{l}\text { I read the feedback carefully and try } \\
\text { to understand what the feedback is } \\
\text { saying. }\end{array}$ & 65 & 13.7 & 107 & 22.6 & 295 & 62.3 & 3.70 \\
\hline & $\begin{array}{l}\text { I use the feedback to go back over } \\
\text { what I have done in the assignment. }\end{array}$ & 78 & 16.4 & 88 & 18.6 & 303 & 64 & 3.70 \\
\hline & $\begin{array}{l}\text { The feedback given with any } \\
\text { subsequent assignments helps me. }\end{array}$ & 68 & 14.4 & 80 & 16.9 & 316 & 66.7 & 4.00 \\
\hline & $\begin{array}{l}\text { The feedback prompts me to go back } \\
\text { over material covered earlier in the } \\
\text { course. }\end{array}$ & 57 & 12 & 64 & 13.5 & 344 & 72.5 & 3.90 \\
\hline ? & the comments & 60 & 12.7 & 96 & 20.3 & 312 & 65.8 & 3.80 \\
\hline & $\begin{array}{l}\text { I use the feedback to compare my } \\
\text { progress with other students. }\end{array}$ & 84 & 17.7 & 127 & 26.8 & 254 & 53.6 & 3.70 \\
\hline & $\begin{array}{l}\text { use the feedback for revising } \\
\text { and }\end{array}$ & 370 & 78 & 43 & 9.1 & 46 & 9.7 & 4.28 \\
\hline & $\begin{array}{l}\text { I acted on suggestions to improve } \\
\text { my coursework. }\end{array}$ & 63 & 13.3 & 50 & 10.5 & 354 & 73.9 & 4.00 \\
\hline 9 & $\begin{array}{l}\text { I have good intentions, but forget } \\
\text { comments for improvement next } \\
\text { time. }\end{array}$ & 373 & 78.7 & 55 & 11.6 & 40 & 8.4 & 4.26 \\
\hline 10 & $\begin{array}{l}\text { I have ignored negative or critical } \\
\text { feedback. }\end{array}$ & 302 & 63.7 & 86 & 18.1 & 75 & 15.9 & 3.73 \\
\hline 11 & $\begin{array}{l}\text { I tend to only read the marks } \\
\text { compared to other students. }\end{array}$ & 324 & 68.3 & 75 & 15.8 & 66 & 13.9 & 3.89 \\
\hline 12 & $\begin{array}{l}\text { After reading comments, I re-work } \\
\text { any assessment task. }\end{array}$ & 91 & 19.2 & 127 & 26.8 & 252 & 53.2 & 3.50 \\
\hline 13 & $\begin{array}{l}\text { I read comments and plan strategies } \\
\text { for future learning. }\end{array}$ & 52 & 10.9 & 76 & 16 & 333 & 70.2 & 4.00 \\
\hline
\end{tabular}

Note: $\mathrm{f}=$ frequency; $\%=$ percentage

In Table 4, the mean values showed that the students use the feedback given by their teachers to improve their learning for the future. However, compared to other items presented to them, the tendency of doing their assessment tasks again after reading comments is low.

While $12.7 \%$ of the students hardly use the feedback given by their teachers, $65.8 \%$ of students regularly read their comments and identify the gaps in their learning for future success. Most students use the feedback given to revise their work $(78 \%)$, to improve tasks given $(73.9 \%)$, and to plan strategies for improvement the next time $(78.7 \%)$. A reasonable number of students $(53.6 \%)$ 
use the feedback given to compare their progress with that of their peers; however, using feedback for comparative purposes has little value for learning, rather, such type of usage undermines the confidence and self-esteem of low achieving students.

Table 5: One sample t-test

\begin{tabular}{lllllll}
\hline Participants & Variable & Expected Mean & Observed mean & SD & t-value & Sig \\
\hline Students & PPFL & 45 & 57.06 & 7.12 & 174.58 & $.000^{*}$ \\
$(\mathrm{~N}=474)$ & PPF & 42 & 47.89 & 6.59 & 158.08 & $.000^{*}$ \\
& Usage & 39 & 49.94 & 7.62 & 142.32 & $.000^{*}$ \\
\hline
\end{tabular}

Note: $P P F L=$ Perception on the power/value of feedback on learning;

$\boldsymbol{P P F}=$ Perception on the practice of feedback; $\boldsymbol{P P}=$ Perceived practice

The one-sample t-test result shows that the observed mean is greater than the expected mean in the case of students' perceptions on the power of feedback to improve their learning and significant difference was observed $(\mathrm{t}=174.58$, $158.08,142.32 ; \mathrm{p}=0.000)$. Thus, we can conclude that students have high and positive perceptions on the power of feedback on their learning. Moreover, students perceived positively the practice of feedback in their schools. The one sample t-test also shows that a significant number of students use the feedback provided by their teachers to improve their learning.

The qualitative data result that was obtained from document review showed that feedback given to students is in the form of marks and words such as 'excellent', 'good', and 'very good' for correct answers. These have no value in showing where students might have learning gaps and does not help them with strategies for future learning.

Table 6: Inter correlation between students' perceptions and usage of feedback

\begin{tabular}{lllll}
\hline & & Usage & PPF & PPFL \\
\hline \multirow{4}{*}{ Usage } & Pearson Correlation & & & \\
& Sig. (2-tailed) & & & \\
& N & 472 & & \\
PPF & Pearson Correlation & $.425^{* *}$ & & \\
& Sig. (2-tailed) & .000 & & \\
& N & 472 & 473 & \\
& Pearson Correlation & $.451^{* *}$ & $.388^{* *}$ & \\
& Sig. (2-tailed) & .000 & .000 & 474 \\
\hline
\end{tabular}

**. Correlation is significant at the 0.01 level (2-tailed).

Note: $\boldsymbol{P P F}=$ Perception on the power/value of feedback on their learning; $\boldsymbol{P P F}=$ Perception on the practice of feedback

The result of Pearson correlation in Table 6 strengthens the above finding. It indicates that there is a significant relationship between students' usage of feedback to improve their learning and their perceptions on the practice of feedback in the classroom $(\mathrm{r}=0.425, \mathrm{n}=472, \mathrm{p}<0.01)$. Moreover, as indicated in 
Table 6, students' perceptions on the power of feedback on their learning has a significant relationship with their perceptions on the practice of feedback $(\mathrm{r}=0.388, \mathrm{n}=473, \mathrm{p}<0.01)$.

Table 7: The multiple regressions model summary and analysis of variance

\begin{tabular}{|c|c|c|c|c|c|c|c|}
\hline Model & & & $\begin{array}{l}\text { Sum of } \\
\text { Squares }\end{array}$ & $\mathrm{df}$ & $\begin{array}{l}\text { Mean } \\
\text { Square }\end{array}$ & F & Sig. \\
\hline Multiple R & 0.52 & Regression & 7458.92 & 2 & 3729.46 & 87.84 & .000 \\
\hline R Square & 0.273 & Residual & 19912.30 & 469 & 42.46 & & \\
\hline Adjusted R & 0.269 & Total & 27371.22 & 471 & & & \\
\hline SEM & 6.52 & & & & & & \\
\hline
\end{tabular}

Note: SEM= Standard Error of the Estimate; $d f=$ Degree of freedom; $F=F$-test

Multiple regression was employed to assess how much variance in students' usage of feedback can be explained by their perceptions on the power of feedback on their learning and the practice of feedback in the classroom (by the two independent variables). The result of the multiple regressions or the adjusted $\mathrm{R}$ square in Table 7 indicates that $26.9 \%$ of the variance in students' feedback usage is attributed to the variance of the combination of the two independent variables (i.e. students' perceptions on the power of feedback and practice of feedback). Moreover, F-test was employed to determine whether the result was statistically significant or not. The result showed that the relationship between the dependent variable and the combination of the two independent variables (perception on the power of feedback and perception on the practice of feedback) was statistically significant at $F(2,469)=87.84, p=0.000$.

Table 8: Significance of the predictor variable

\begin{tabular}{lccccc}
\hline Variable & B & SE & Beta & t & Sig \\
\hline PPFL & .375 & .045 & .350 & 8.290 & .000 \\
PPF & .302 & .045 & .282 & 6.676 & .000 \\
\hline
\end{tabular}

Note: $B=$ Beta for unstandardized coefficient; $S E=$ Standard Error; $t=t$-test; $P P F L=$ Perception on the power/value of feedback on their learning; $P P F=$ Perception on the practice of feedback

The t-test result showed that from the two independent variables (PPFT and PPF), students' perceptions on the power of feedback on their learning makes a major significant contribution to explain the dependent variable when the variance accounted by all other variables in the model is controlled for (beta = 0.35). Students' perceptions on the practice of feedback in the classroom also made a statistically significant $(p=0.000<0.01)$ contribution (beta $=0.282)$ to the regression model.

\section{Discussion}

\subsection{Students' perception on the value and practice of feedback}

To provide students with the best opportunity to improve their knowledge and necessary skills in a required subject, it is essential that teachers are aware of their feedback styles, nature, and purpose. According to Weaver (2006), the nature and style of feedback provided by teachers can affect the way students 
perceive and use feedback in their learning. Thus, the way teachers value and provide feedback will affect students' usage and perception of it.

The results of the study showed that students positively perceive the value of feedback in improving their learning. This result is in line with Weaver (2006) and recommends that improvement in learning occurs when students perceive feedback as enabling learning, and not just as a judgment on their level of achievement. Moreover, most students in this study positively perceived the practice of feedback in their schools, yet the qualitative data indicated that the provision of feedback to improve students' learning is not practiced in the way it should be. This mismatch between the qualitative and quantitative result suggests that students might not really understand the nature, form, and content of the feedback needed to improve learning. Most of them consider effective feedback as a provision of marks, grades, and correct answers, but it is more than these.

Research evidence shows that teachers need to review their beliefs and understanding on the purpose, language, and content of feedback they provide (Weaver, 2006), as it will then have a better connection with that of students and help address their main concerns. According to Orsmond and Merry (2011), student responses to feedback were influenced by their perception of the teacher giving the feedback. For example, the results of this study suggest that students considered the provision of marks, correct answers, and praise as effective feedback to improving learning.

\subsection{Students' use of feedback to improve their learning}

Hattie and Timperley (2007) argued that the main purpose of feedback is to reduce the gap between students' current understanding and the learning objectives stated in the subject. Therefore, for Hattie and Timperley, feedback must help students answer these questions: where am I going, how am I going, and where to go next? However, as indicated in different literature, all types of feedback do not assist students to improve their learning. For example, even if the results of this study indicates that students are perceived as they are using the feedback given by their teachers to enhance their learning, they did not get the feedback on different assessment tasks on time and the tendency of doing their assessment tasks again after reading the comments given by their teachers is low. According to Amua-Sekyi (2016, p. 4), "when feedback on students' work is delayed, it loses its relevance".

On the other hand, a reasonable number of students (53.6\%) in this study use the feedback given to compare their progress with that of their peers; however, using feedback for comparative purposes has little value for learning and this type of usage can undermine the confidence and self-esteem of those students that are low achievers (Dinnen \& Collopy, 2009). Lee (2006) suggested that for feedback to be effective it must inform the student how to improve; specific suggested actions must be clearly stated so that the student can act on them. 
Similarly, Weaver (2006) claimed that students might not use feedback to improve their learning; some feedback may be limited and not point the way forward or motivate students to take further action, or they may have insufficient understanding of the subject matter to interpret comments accurately. When a teacher corrects all mistakes or copyedits written work, the student does not get an opportunity to figure anything out and to implement different strategies in their next steps in learning.

Generally, even if students perceive they are using feedback to improve their learning, the way they use the feedback provided is not appropriate for their further learning. This happens because of the nature, content, and purpose of feedback provided to them and teachers' misconceptions on the nature of effective feedback.

\section{Conclusion}

Most of the students in the selected schools perceived that teachers' feedback is effective to promote their learning, to reflect on what they have learned, and to identify the learning gaps. To improve students' learning and confidence, the feedback given should be clear, positive, and constructive. The feedback given to students helps them to understand things better and shows how to improve on their future tasks. The results of this study show that the students use the feedback given by their teachers to improve their learning, however, the tendency of doing their assessment tasks again after reading the comments given by their teachers is low. A reasonable number of students use the feedback given to compare their progress with that of their peers; however, using feedback for comparative purposes has little value for learning, especially as such comparisons undermine the confidence and self-esteem of low achieving students. Students have a high and positive perception on the value of feedback on their learning. Moreover, students positively perceive the practice of feedback in their schools. The results also showed that students, to a large degree, use the feedback provided by their teachers to improve their learning. The significant relationship observed between students' usage of feedback and students' perceptions on the practice of feedback in the classroom helps improve their learning. Moreover, the significant relationship between the students' perceptions on the power of feedback and their perceptions on the practice of feedback also improves their learning. Judgmental feedback using words such as 'excellent', 'very good', and 'good', were used in the students' exercise books which has little value in showing learning gaps and strategies for future learning and this type of feedback is not effective in improving students' learning. Effective feedback is constructive and shows the gaps in understanding and suggests ways for the students to fill those gaps in the future by themselves. Therefore, for feedback to be meaningful, students should have a positive perception of feedback and take the feedback into account for future learning to enhance their knowledge and understanding. 


\section{References}

Acar-Erdol, T., \& Yildizli, H. (2018). Classroom assessment practices of teachers in Turkey. International Journal of Instruction, 11(3), 587-602. https://doi.org/10.12973/iji.2018.11340a

Amua-Sekyi, E. T. (2016). Assessment, student learning and classroom practice: A review. Journal of Education and Practice, 7(21), 1-6.

Ansari, T., \& Usmani, A. (2018). Students' perception towards feedback in clinical sciences in an outcome-based integrated curriculum. Pakistan Journal of Medical Science, 34(3), 702-709. doi: https://doi.org/10.12669/pjms.343.15021

Brookhart, S. M. (2008). How to give effective feedback to your students. ASCD: Virginia.

Carless, D. (2006). Differing perceptions in the feedback process. Studies in Higher Education, 31(2), 219-233. doi: 10.1080/03075070600572132

Cohen, L., Manion, L., \& Morrison, K. (2018). Research methods in education (8th ed.). New York: Routledge.

Creswell, J. (2007). Qualitative inquiry and research design: Choosing among five approaches ( $2^{\text {nd }}$ ed.). University of Nebraska: Sage Publications Ltd.

De Vos, A. S., Strydom, H., Fouche, C. B., \& Delport, C. S. L. (2011). Research at grass roots: For the social science and human service professions ( $4^{\text {th }}$ ed.). Pretoria: Van Schaik.

Di Costa, N. (2010). Feedback on feedback: Student and academic perceptions, expectations and practices within an undergraduate Pharmacy course. ATN Assessment Conference, University of Technology, Sydney.

Dinnen, J. L. D., \& Collopy, R. M. B. (2009). An analysis of feedback given to strong and weak student writers. Teacher Education Faculty Publications, 49(3), 239-256.

Fautley, M., \& Savage, J. (2008). Assessment for learning and teaching in secondary schools. British: Learning Matters Ltd.

George, D., \& Mallery, P. (2016). IBM SPSS statistics 23 Step by step: A simple guide and reference. New York: Routledge.

Hattie, J., \& Timperley, H. (2007). The power of feedback. Review of Educational Research, $77(1), 81-112$.

Irons, A. (2008). Enhancing learning through formative assessment and feedback. New York: Routledge.

Lee, C. (2006). Language for learning mathematics: Assessment for learning in practice. New York: Open University press.

Li, J., \& De Luca, R. (2014). Review of assessment feedback. Studies in Higher Education, 39(2), 378-393, https://doi.org/10.1080/03075079.2012.709494

Marrs, S. A. (2016). Development of the student perceptions of writing feedback scale (Unpublished doctoral dissertation). Virginia Commonwealth University, Richmond, Virginia.

Moss, C. M., \& Brookhart S. M. (2009). Advancing formative assessment in every classroom. Virginia: ASCD.

Nicola, D. J., \& Macfarlane-Dick, D. (2006). Formative assessment and self-regulated learning: A model and seven principle of good feedback practice. Studies in Higher Education, 31(2), 199-218.

Oluwatayo, G. K., Irene, W., \& Appah, O. R. (2014). Assessment of university lecturers' feedback in formative tests. Journal of Educational Review, 7(1), 119-127.

Orsmond, P., \& Merry, S. (2011). Feedback alignment: Effective and ineffective links between tutors' and students' understanding of coursework feedback. Assessment \& Evaluation in Higher Education, 36(2), 125-136.

Price, M., Handley, K., Millar, J., \& O'Donovan, B. (2010). Feedback: All that effort, but what is the effect? Assessment \& Evaluation in Higher Education, 35(3), 277-289. 
Sadler, D. R. (2010). Beyond feedback: Developing student's capability in complex appraisal. Assessment and Evaluation in Higher Education, 35(5), 535-550.

Tan, F. D. H., Whipp, P. R., Gagné, M. \& Quaquebeke, N. V. (2019). Students' perception of teachers' two-way feedback interactions that impact learning. Social Psychology of Education, 22: 169-187. https://doi.org/10.1007/s11218-018-9473-7

Spiller, D. (2014). Assessment: Feedback to promote students learning. Teaching Development Unit, The University of Waikato.

Sutton, R., Hornsey, M. J., \& Douglas, K. M. (2011). Feedback: The communication of praise, criticism, and advice. New York: Peter Lang Publishing.

Van Der Kleij, F., \& Adie, L. (2020). Towards effective feedback: An investigation of teachers' and students' perceptions of oral feedback in classroom practice. Assessment in Education: Principles, Policy \& Practice, 27(3), 252-270. https://doi.org/10.1080/0969594X.2020.1748871

Weaver, M. R. (2006). Do students value feedback? Student perceptions of tutors' written responses. Assessment \& Evaluation in Higher Education, 31(3), 379-394.

\section{Appendix 1}

\section{Questionnaire to be filled by Students}

\section{Dear students,}

This questionnaire is designed to gather information for the research entitled “The Value of Feedback in Primary Schools: Students' Perceptions of the Practice." Thus, the main objective of this questionnaire is to assess students' perceptions and practice of feedback to improve students' learning. So, you are kindly requested to provide genuine information, which is very important to the quality of the research.

Your cooperation in this regard will be highly solicited. All of your responses will be kept confidential.

Thank you in advance for your cooperation.

\section{Part I: - Students' perceptions on the value of feedback}

Direction:- Please indicate how much you agree or disagree with the following statements putting a tick mark $(\sqrt{ })$ in the box

Level of agreement $5=$ Strongly Agree $3=$ Unable to decide

$$
4=\text { Agree } \quad 2=\text { Disagree } \quad 1=\text { Strongly Disagree }
$$

\begin{tabular}{|l|l|l|l|l|l|l|}
\hline No. & \multicolumn{1}{|c|}{ Statement } & \multicolumn{3}{|c|}{ Level of Agreement } \\
\cline { 5 - 7 } & & $\mathbf{5}$ & $\mathbf{4}$ & $\mathbf{3}$ & $\mathbf{2}$ & $\mathbf{1}$ \\
\hline 1 & $\begin{array}{l}\text { Feedback is helpful to show gaps in knowledge and } \\
\text { understanding. }\end{array}$ & & & & \\
\hline 2 & $\begin{array}{l}\text { Feedback rarely provides me with useful suggestions for } \\
\text { improvement. }\end{array}$ & & & & & \\
\hline 3 & I consider that peer feedback is essential for learning. & & & & \\
\hline 4 & Teacher feedback is effective in promoting students' learning. & & & & & \\
\hline 5 & Constructive criticism is needed to know how to improve my & & & & & \\
\hline
\end{tabular}




\begin{tabular}{|l|l|l|l|l|l|l|}
\hline & work. & & & & & \\
\hline 6 & Feedback given at the end of the subject is not useful. & & & & & \\
\hline 7 & The feedback which is given should be clear to be helpful. & & & & & \\
\hline 8 & Feedback encouraged me to improve my work. & & & & & \\
\hline 9 & Positive comments increase my confidence. & & & & & \\
\hline 10 & I thought about giving up when I got negative feedback. & & & & & \\
\hline 11 & I felt demoralized or angry after reading negative feedback. & & & & & \\
\hline 12 & Feedback has helped me to reflect on what I have learned. & & & & & \\
\hline 13 & I need to receive positive feedback to progress. & & & & & \\
\hline 14 & I need to receive negative feedback to progress. & & & & & \\
\hline 15 & Teachers' comments are vital in my learning. & & & & & \\
\hline
\end{tabular}

\section{Part II: Students' perceptions of the practice of feedback}

Direction:- Please indicate how much you agree or disagree with the following statements putting a tick mark $(\sqrt{ })$ in the box

$$
\begin{aligned}
& \text { Level of agreement } \quad 5=\text { Strongly Agree } \quad 3=\text { Unable to decide } \\
& 4=\text { Agree } \quad 2=\text { Disagree } 1=\text { Strongly Disagree }
\end{aligned}
$$

\begin{tabular}{|l|l|l|l|l|l|}
\hline No & \multicolumn{1}{|c|}{ Statement } & \multicolumn{1}{|c|}{ Level of Agreement } \\
\hline & & $\mathbf{5}$ & $\mathbf{3}$ & $\mathbf{2}$ & $\mathbf{1}$ \\
\hline 1 & & & & & \\
\hline 2 & On the subject that I am learning, I get plenty of feedback on \\
how I am doing. & Teachers give me immediate feedback for each assessment. & & & & \\
\hline 3 & $\begin{array}{l}\text { There is hardly any feedback on my assignments when I get } \\
\text { them back. }\end{array}$ & & & & \\
\hline 4 & $\begin{array}{l}\text { When I get things wrong, I don't receive much guidance in what to do } \\
\text { about it. }\end{array}$ & & & & \\
\hline 5 & I would learn more if I received more feedback. & & & \\
\hline 6 & Teachers' feedback that comes too late is not useful for learning. & & & & \\
\hline 7 & Teachers provide enough feedback on my work. & & & \\
\hline 8 & $\begin{array}{l}\text { The feedback mainly tells me how well I am doing in relation to } \\
\text { others. }\end{array}$ & & & & \\
\hline 9 & $\begin{array}{l}\text { Teachers' feedback is rarely written with reference to the } \\
\text { assessment criteria. }\end{array}$ & & & & \\
\hline 10 & The feedback given helps me to understand things better. & & & & \\
\hline 11 & The feedback given shows me how to do better next time. & & & & \\
\hline 12 & $\begin{array}{l}\text { Once I have read the feedback, I understand why I got the mark } \\
\text { I did. }\end{array}$ & & & & \\
\hline 13 & I don't understand some of the feedback given. & & & & \\
\hline 14 & $\begin{array}{l}\text { I can seldom see from the feedback given what I need to do to } \\
\text { improve. }\end{array}$ & & & & \\
\hline
\end{tabular}




\section{Part III. Students use of feedback to improve their learning}

Direction:- Judge to what degree you are using feedback and give your response by putting a tick " $\sqrt{ }$ " mark in one of the boxes under the alternative scales given.

$$
5=\text { Always } \quad 4=\text { Often } \quad 3 \text { = Sometimes } \quad 2 \text { = Rarely } \quad 1=\text { Never }
$$

\begin{tabular}{|l|l|l|l|l|l|}
\hline $\begin{array}{c}\text { No } \\
\text { Statement }\end{array}$ & $\mathbf{5}$ & $\mathbf{4}$ & $\mathbf{3}$ & $\mathbf{2}$ & $\mathbf{1}$ \\
\hline 1 & $\begin{array}{l}\text { I read the feedback carefully and try to understand what the } \\
\text { feedback is saying. }\end{array}$ & & & & \\
\hline 2 & $\begin{array}{l}\text { I use the feedback to go back over what I have done in the } \\
\text { assignment. }\end{array}$ & & & & \\
\hline 3 & $\begin{array}{l}\text { The feedback given with any subsequent assignments helps } \\
\text { me. }\end{array}$ & & & \\
\hline 4 & $\begin{array}{l}\text { The feedback prompts me to go back over material covered } \\
\text { earlier in the course. }\end{array}$ & & & \\
\hline 5 & $\begin{array}{l}\text { I read the comments carefully and identify the gaps in my } \\
\text { learning }\end{array}$ & & & \\
\hline 6 & I use the feedback to compare my progress with other students & & & & \\
\hline 7 & I do not use the feedback for revising my work & & & & \\
\hline 8 & $\begin{array}{l}\text { I acted on suggestions to improve my coursework. } \\
\text { I have good intentions, but forget comments for improvement } \\
\text { next time. }\end{array}$ & & & & \\
\hline 10 & I have ignored negative or critical feedback. & & & & \\
\hline 11 & I tend to only read the marks compared to other students. & & & & \\
\hline 12 & After reading comments, I re-work any assessment task. & & & & \\
\hline 13 & I read comments and plan strategies for future learning. & & & & \\
\hline
\end{tabular}

